\title{
浅析新时代高校思想政治教育建设创新
}

\author{
彭鹏 \\ 吉林大学管理学院 \\ DOI:10.32629/er.v2i7.1930
}

[摘要] “互联网+” “大数据” “新媒体”不断地冲击着传统的高校教育,冲击着传统的学生工作模式。在新时代下,高校对 传统的思政教育模式进行创新何其重要, 又应该以怎样的姿态来应对这种挑战? 创新学生思政教育模式,积极探索适应时代要 求的高校学生思政教育模式为社会培养和输送更多合格的人才,成为当务之急。

[关键词] 高校; 思想政治教育; 创新

\section{1 新时代的思政教育}

在思政教育过程中, 思想教育工作能够实现整合创新, 将提升大学生人文素养, 营造一个良好的教学环境。在信息 技术蓬勃发展和社会经济巨大变迁的背景下, 大学生思政教 育方式也发生了重大变革。大学思想政治教学摸式也迎来了 新时代和新形势的挑战, 因此只有成功应对挑战, 完成大学 生思政教育模式的有效创新, 才能使大学思政教育工作能够 稳定持续的发展。

\section{2 新时代高校思政教育的创新建设}

2.1新时代下高校思政教育创新的必要性

2.1.1保证民族团结、培养良好品质

传统思想政治教育虽不完善, 却也培养了一代又一代的 人才, 更是培养了爱国、敬业、诚信、友善等良好品质。进 行思政工作机制创新有利于对于这些良好品质的继承和发 展, 更有利于做到 “两个维护” , 保障民族团结, 维护人民利 益和国家主权。

\section{1.2 保障社会主义意识形态}

近年来, 大学生乃至社会各阶层的思想都或多或少受到 西方资本主义意识形态的侵蚀, 主要表现为抵触我国社会主 义建设和党的领导。欧美国家惯用的和平演变战略基本思路 便是在社会主义国家内部创造一场 “和平竞赛” , 促使社会 主义制度从内部解体。我们必须加强警惕, 通过思政教育来 巩固中国特色社会主义文化, 学习习近平新时代中国特色社 会主义思想, 深刻领会新时代中国特色社会主义思想的实质 内涵, 筑牢社会主义意识形态。

\section{2 新时代下高校思政教育创新面临的挑战}

\subsection{1 高校思政教育要适应新环境}

互联网多媒体的迅速发展并没有给传统意义上的思政 教育带来多大的改变, 思政教育还是停留在以往单一的教学 方式中, 教育者在互联网的冲击下依旧按部就班地进行思想 政治教育, 教学手段及教学方式的陈旧, 使学生没有办法与 教师产生思想上的共鸣, 无法受到相应的思政教育。教育与 时代的脱轨, 在思政教育中表现得尤为明显。学生对知识的 汲取, 早已不仅仅局限于学校学习, 通过手机连接互联网, 基 本上随时随地都能够进行学习, 学习的范围更加广泛。高校
的思政教育却还是停留在以往的教学层面上, 不仅跟不上时 代的脚步, 更无法满足学生的学习需求。

2.2.2西方外国文化的冲击

西方后现代主义等不良思潮对我国高校思政教育工作 产生冲击。目前西方部分国家已进入后工业化时代, 这些国 家依靠自身科技与经济的软实力, 不断向中国渗透他们的价 值标准、文化观念、意识形态等精神内容, 这就使得大学生 在无意识的情况下潜移默化地受到他们思想观念的影响。而 我国高校思想政治教育理念更新缓慢导致相关教学工作被动 适应环境的变化, 使得高校思想政治教育在育人功能上打折。

2.2.3 高校思政教育的灌输方式使教学效果的弱化

当前, 大部分高校思想政治教育过程采取传统的自上而 下的保守灌输方式, 大多在强调思想的统一性和政治的正确 性, 而忽视了当前的大学生本身的多样化的自主人文需求, 造成大学生偶有抵触高校思想政治教育内容的情况。当前大 学生的高校生活相对开放、独立, 网络不良信息的泛滥使大 学生出现了信仰危机、价值迷茫和心理健康等各种各样的问 题, 因而高校思想政治教育工作在面对学生千差万别的复杂 思想状况时亟需提供多样化的个性服务, 如心理疏导、人文 关怀以及解惑答疑等。再者, 随着微博、微信等新媒体的迅 速发展, 大学生接触信息的渠道日趋多元, 因而其思维方式 和行为习惯等都发生了历史性的变化。大学生对社会、政治、 文化等多方面的认知不再单纯的依靠高校教育者, 而是更多 地从网络信息中吸取知识, 这也就造成了当代大学生思想观 念、价值取向向多元发展, 高校思政教育内容的影响力呈现 弱化趋势。

\section{3新时代下高校思政教育的创新途径}

2. 3. 1 熟练应用新媒体技术, 建立高校网络教育平台

当前, 社会已经逐步进入了网络信息化的时代, 依托于 信息科学技术, 新媒体逐渐成为网络媒体的新起之秀, 并受 到广大人民群众的热捧和好评, 得到了广泛的使用。尤其是 微博、微信、QQ以及博客、论坛等新媒体平台在高校大学生 中得到了广泛的使用, 依托于移动终端技术, 新媒体客户端 及网络平台就成为了高校大学生的聚集地 ${ }^{[1]}$ 。针对这种现象, 高校思政教育工作者要及时创新思政教育的思路, 摒弃传统 
的思政教育模式, 充分利用新媒体在大学生中的影响力, 开 展高校思政教育工作。熟练地使用现在流行的通信工具, 组 织并开展多种形式的思政教育, 把新媒体作为开展高校思政 教育工作的新媒介和渠道, 创新高校思政的工作思路, 为学 生建立校园网络教育平台, 将积极向上的、健康励志的 思想 和事迹传播给大学生, 使学生加深对思政教育的认识和理解, 并在潜移默化中喜欢并认同思政教育, 吸收正能量的信息, 从而提高高校思政教育工作的实效性。

\subsection{2高校思政教育工作运行机制创新}

过于强调考试结果而非学习过程的思政教育课程、陈旧 的思想政治教育方法等都易使大学生对思政教育产生抵触、 逆反心理。针对传统的 “出勤-作业-期末考试” 这种亘古不 变的形式, 学生也针对这种情况总结出一套 “上课-下课-抄 作业-期末临时突击” 的方法, 针对大学生的逆反心理, 高校 得从源头抓起, 寓教于乐, 使思政教育摆脱形式化。一方面, 辅导员可以利用其了解学生的优势承担双重角色, 在做好学 生日常思想教育管理工作的同时, 承担思想政治理论课的教 学任务, 以互化思政教师和辅导员的角色和工作职能。另一 方面可以可以在培养中设置充足的实践培养时间。目前我国 思政教育工作以思政课为主体, 而思政课的形式较为单一, 缺乏实践课程。高校思政教育体系可以在人才培养方案中 设置充足的修读课程时间, 加强实践课程的开发建设, 在实 践中提升思想教育效果。主要可以从大力加强以青年志愿者 服务为主要内容的大学生社会实践教育入手。

\subsection{3高校思政教育与慕课教学相结合}

在当下互联网的大力发展下, “互联网+教育” 的模式应 运而生。慕课就是当下互联网与教育相结合的成果。慕课打 破了时间和空间的限制, 形成了开放共享的优质教学资源, 可使教育 效果最优化 ${ }^{[2]}$ 。学生可以利用线上课堂进行自主 探究, 利用线下课堂开展研讨、交流, 教师总结学生提出的问
题, 答疑解惑, 及时反馈, 加深学生对知识的理解, 培养学生 学习的主观能动性, 突出课堂教学的针对性优质教育。除此 之外,一般情况下资源都是制约高校思政教育进一步发展的 关键所在, 在传统思政教育中, 教师行政归属阻碍了教育资 源的实现, 而 “互联网+教育” 在高校思政教育中的应用则可 以有效打破这一现状, 推动优质教育资源的动态流动 ${ }^{[3]}$ 。通 过新媒体、专业思政教育平台的应用, 学生可以连接到不同 平台中进行思政知识学习, 同时学校之间也可以通过合作开 发、购买等方式引进大量的优质思政教育资源, 满足学生对 优质教育资源的实际需求。综上, “互联网 + ” 时代下的教育, 是一种新型的教育模式, 模糊了时间、空间的概念, 采用 “寓 教于乐” 游戏化的学习方式, 以求达到教学活动的最佳效果。

\section{3 结语}

思政教育在当今大学生的教育教学工作中占据着重要 的地位, 要想抓好大学生未来的发展方向, 首先要让其树立 正确的思想政治观念, 这不仅是对大学生自身素质提高的要 求, 同样也是社会给予大学生的责任和期望。在新时代创新 的浪潮冲击下, 高校应理智应对目前思政教育面临的挑战, 引进新的理念, 依托互联网技术进行自我改革创新从而迎来 更深更远的发展。

[参考文献]

[1]齐琳娜.新媒体视域下高校思政工作思路创新探究 [J].新媒体研究,2015,(6):28-29.

[2]宋军涛.高校思政教育模式的重构一以新时代 “互 联网+”发展为背景[J]. 陕西教育(高教),2018,(09):12-13.

[3]金素端. “互联网+”时代高校思政课教学实效性的 提升路径[J].高教学刊,2017,(14):71-73.

作者简介：

彭鹏(1982--), 男, 吉林长春人, 汉族, 管理学硕士, 讲师, 从 事工作：大学生思想政治教育及管理工作。 